[Simpkin, G. (1996). Overcoming the Bulk Funding Blockage: The Ministerial Reference Group on School Staffing. New Zealand Annual Review of Education, 5, 57-74]

\section{Overcoming the Bulk Funding Blockage: The Ministerial Reference Group on School Staffing}

\section{GAY SIMPKIN}

\section{Abstract:}

The report of the Ministerial Reference Group on school staffing, while ostensibly addressing the mechanism by which the supply of teachers to schools is calculated, has greater significance for schools. Its recommendations appear to be related to neo-liberal theories of the state. Not only do they provide another opportunity for schools to choose to be bulk funded for teacher salaries, but they also introduce competition between schools by reducing staffing levels in smaller schools, and by providing capped contestable pools of funds for which schools must compete. The article explores the implications of these developments for the national collective contracts of teachers.

$\mathrm{T}$ The report of the Ministerial Reference Group entitled Resource Entitlement for School Staffing was released in February 1995 by the Ministry of Education. Due for implementation in 1996, the report, despite its straightforward title, contains policy which represents a significant shift towards the neo-liberal agenda for schools. Publicity surrounding it has focussed on only one area of conflict over the policy - the contentious political issue of the bulk funding of teachers' salaries. The report, however, bears closer scrutiny. It lays out explicit mechanisms for achieving the same ends as the complete devolution of financial control to Boards of Trustees was expected to achieve implicitly (see, for example, the arguments of Gordon, 1992; Lauder, 1991; Snook, 1995)

In what follows, the content of the report is looked at in depth, and related to theories regarding the purpose of teacher salaries bulk funding. The implementation of the report is related to the continuing political contestation of the policy, and it will be argued that because teacher unions and Boards of Trustees continue to oppose bulk funding, with some success, the goals of the policy are being addressed more explicitly through changes to the system of staffing primary and secondary schools. A brief account of the political progress of these changes through the Schools' Consultative Group (SCG) and the Ministerial Reference Group (MRG) is given. ${ }^{1}$

\section{The Story Over Bulk Funding So Far}

Gordon (1992) in her analysis of the bulk funding of teachers' salaries presents the issue as a case study in education policy arising from the restructuring of the state in the 1980s. The theoretical components of the Tomorrow's Schools policy, she argues, were a combination of principles arising from a form of neo-liberal monetarism, including public choice theory; concern with the processes and accountability of state action; and a crisis of legitimation within the state. This was not unique to changes in education, and can be seen elsewhere in the state system, such as in health and core state services. Gordon postulates that the Labour Government's attempt to combine neo-liberal state reforms with a commitment to equity and community participation led to a delay in the implementation of the bulk funding policy, reflecting the contradictory political position of its members. The National Government came to power with no such commitment, and immediately set about implementing bulk funding.

Gordon documents to the end of 1991 the political strategies of both the Government and the teacher unions, directed at implementing and opposing bulk funding, respectively. At that time, a bulk funding trial was due to proceed with 45 schools in 1992. While this was progress towards implementation, it represented a less-than-ideal outcome from the Government's point of view. From the teacher unions' point of view, again it was less-than-ideal, because some ground had been lost, but their campaign opposing the policy was justified by the small number of schools opting into the trial

The years following 1991 saw periodic reporting on the Salaries Bulk Funding trial, which came to be known as the Teacher Salaries Grant Scheme (TAG) trial. Dr Wayne Edwards of Massey University was contracted by the Ministry of Education to carry out a research project evaluating the trial. His research was based on interviews and questionnaires given to board members, principals and teachers in trial schools. A first interim report was presented to the Ministry of Education in May 1993, and a second report in May 1994. Of particular relevance to the argument which follows are the observations that the majority of trial schools stood to gain financially from the additional income or 
anticipated savings, and that in schools where the TAG trial was not initially supported by staff there remained a "climate of unease" (Edwards, 1994, p. 68). A difference was reported between those involved practically in the implementation of TAG, mainly admin-istrators (who welcomed the practical benefits), and others, primarily teachers, who spoke from a more philosophical perspective, and were concerned for the long-term effects of the TAG on the national system of education (Edwards, 1993).

In 1992 further progress towards full bulk funding was made, with payments for relief teachers becoming part of the Operational Bulk Fund, and with the introduction of the Salaries Grant for Management (SGM), which delivered payments in cash for salaries for management positions in schools. While, superficially, activity appeared to be dormant through 1993 and 1994, much was happening in two forums, through the staffing sub-committee of the Schools' Consultative Group (SCG) and subsequently in the Ministerial Reference Group (MRG) on school staffing. A summary of events occurring in these two groups is given after a discussion of the policy goals of the Salaries Bulk Fund and an outline of the proposals of the MRG.

\section{Policy Goals of Salaries Bulk Funding}

Gordon sees the introduction of bulk funding as a crucial means of disengaging and distancing the state from the determination of teachers' salaries and conditions. Once bulk funding is fully introduced, the structures will exist to break down national collective contracts for teachers into individual school collective contracts, with bargaining between Boards of Trustees and site-based unions. Gordon sees this as an opportunity for greater state control over, and possible reductions in, school budgets.

Certainly, teachers in the schools sector have led a remarkably charmed life compared with personnel in other sectors of the state, such as health, and early childhood and tertiary education. There have not been the same staffing level reductions, nor has the sector seen the breakdown of national collective contracts into collective contracts at enterprise level. This can be attributed to the delay in implementing bulk funding. The lack of budget control and full bargaining powers over collective contracts by Boards of Trustees has meant that it has not been possible to initiate the breakup of the national collective contracts for teachers, as has happened in both the tertiary and early childhood sectors. Although Boards of Trustees, along with teachers, have largely opposed salaries bulk funding, and most show little desire to be involved in bargaining site contracts, precedents in the tertiary sector show increasing Government pressure on employing bodies towards site contracts, once full employer powers are granted.

In polytechnics and colleges of education, first of all bulk funding was introduced, and then, utilizing the provisions of the Employment Contracts Act, employers refused to negotiate on national collective contracts, under strong encouragement from Government Ministers. The union involved in bargaining in these institutions, the Association of Staff in Tertiary Education (ASTE) was then forced to negotiate over site contracts. In the kindergarten area, Auckland employers have set in place a regional collective contract by the same means, but as yet other kindergarten employers have not followed suit.

For the Government, the delay in bulk funding schools has meant that, prior to the MRG Report, they were still paying for total numbers of teachers fixed by formulae based on class size and numbers of courses provided in each school. The flexibility of bulk funding for Government lies in the ability to cap total funding, forcing governing authorities to use virement between budget lines, to reduce staffing levels over time in order to meet commitments elsewhere. This has happened in England and Wales under the Local Management of Schools scheme, which confers full bulk funding (including teacher salaries) upon schools. In the years since the UK Education Reform Act, 1988, reports have appeared regularly in the Times Educational Supplement about British schools forced to lay off teachers in order to make ends meet (see, for only two examples, Dean \& McGill, 1994; Maxwell \& Rafferty, 1995).

In her 1992 article, Gordon makes a critical point for the arguments of this paper. She states that from April or May 1991 a major shift took place in the justification for bulk funding. "Instead of empowerment, competition became the central ideology" (p. 46). As will be described below, blocked from the achievement of full bulk funding for schools (and thus from competitive site contracts), the Minister of Education has found other means to achieve this.

The teacher unions have argued that bulk funding, if held to a constant level, ultimately achieves a reduction in cost to the state. There is some evidence in New Zealand to support this argument. The operational bulk fund was held at the same level for individual schools right from implementation of the policy in 1990 until the Budget announcement of an increase in 1994. This is not to argue that commitment to bulk funding on the part of the Minister of Education is a plot to reduce funding to all schools, but as Wylie argues (1995), the model of devolution implemented in the public sector reforms as a whole 
was designed to hold individual institutions accountable for use of funding, rather than hold government accountable for levels of funding. Thus the new public management framework behind the reforms hoped to achieve efficiency gains from funding devolution. Wylie further reported that because of the delay in implementing bulk funding in the schools sector, there is little evidence to date that parents hold trustees responsible for problems in schools arising from funding.

Thus, blocked from achievement of total bulk funding for all schools (an ideal method for Government to achieve these efficiencies or reductions in costs of services), it could be argued that the Government has shifted its policy emphasis towards competition between schools to achieve these same efficiencies.

\section{The Contents of the MRG Report}

The MRG has achieved a reduction of staffing levels in some schools, from the centre, through devising formulae which advantage larger schools at the expense of smaller. The effect of this differs between primary schools and those offering education to Form 1 and above. At the primary level, the effect has been to iron out the relative advantage of small schools compared with larger schools. The effect for schools enrolling children in Form 1 and above is to reduce staffing levels for smaller schools and increase them for larger schools. The staffing changes have been combined with the explicit introduction of competition for two capped contestable funds. One is for Innovative Approaches to Curriculum Delivery for Rural Schools (\$3 million); the other is directed to Senior Secondary Programmes (\$15.7 million), later to be called the Secondary-Tertiary Alignment Resource (STAR). After the publication of the MRG Report, a third fund was introduced, for Students at Risk (\$1.5 million), directed at schools wishing to introduce innovative approaches to assisting such students. Other resource pools for which schools may apply also exist (e.g., Maori Language Resourcing), but these tend to be allocated on a per-pupil or formula basis.

Thus, the reduction in staffing levels for some schools has been achieved overtly by means of the MRG. Competition has also been introduced overtly. It appears that a very skilful step towards the goals of bulk funding has been achieved by Government, without a substantial increase in the number of schools opting for bulk funding itself, a choice again offered to Boards of Trustees as part of the report's recommendations. By the end of March 1996, an additional 122 schools had opted to join the original 69 schools and accept full bulk funding.
The significant changes brought about by the MRG Report can be related to the policy goals of salaries bulk funding outlined above, even though very little of the report deals with bulk funding as such. It is ostensibly about the staffing systems of primary and secondary schools. Its main features, which will be examined in more detail below, are as follows:

- A unified staffing system is proposed, based upon formulae which apply to both primary and secondary schools;

- The removal and transferral of teachers will occur, via the formula, from smaller schools to larger schools providing education for children of Form 1 and above. The formula also provides for approximately 1000 additional teachers nationwide, all of whom are distributed to the larger schools, some two-thirds of the total;

- A contestable, that is, competitive, pool of funding has been created for innovative curriculum delivery in smaller or rural schools;

- A contestable pool of funding has been created for senior school programmes;

- Some schools which used to receive extra staffing for special needs, in particular those in lower socio-economic areas and those with multi-ethnic student populations, have lost those teachers. They now have to compete along with others for extra resources from contestable pools. There is no guarantee that they will have the same level of funding reinstated to allow them to replace the teachers they have lost;

- Schools are again offered the opportunity to opt in to bulk funding. They may opt to continue to have teaching salaries paid centrally and management salaries paid through the SGM; or to receive the resource entitlement in cash with the potential for virement. If they opt for the second alternative, they will receive the average salary for the number of teachers to which they are entitled, plus an extra 1.5\% loading. Once again, as in the TAG trial, extra funds are being supplied to ensure that schools will not have to reduce staffinglevels, in the short term.

\section{Effect of MRG Proposals}

Each of these developments will be considered in turn.

1. New formulae by which schools calculate the number of teachers they are entitled to employ have been developed. For the first time, 
both primary and secondary schools will calculate their staffing entitlement by the same formula. The resulting formulae are, by and large, primary school-based calculations, in which the teacher/ student ratio corresponds in theory with what happens in practice. That is, to all intents and purposes, the number of pupils in a primary classroom matches the number of pupils set out in the teacher/student ratio. In secondary schools, while a teacher/student ratio can be used to determine the total number of teachers employed in a school, it does not reflect the size of classes, which vary according to the popularity of course options and the number of management staff employed. Some classes can be quite large, compensating for less popular course options with smaller classes. The new formulae therefore obscure what is actually happening in secondary classrooms and schools as a whole.

The significance of the unified staffing formulae for future structures of schools is that they seem to imply a unified method of delivery of the curriculum. Leaving educational arguments aside over the desirability, or otherwise, of this, the change puts pressure on traditional definitions of what constitutes primary and secondary schools. It reinforces the breakdown of the structural distinction between primary and secondary education contained in proposals for middle schools which would traverse intermediate and secondary school boundaries. Some full primary schools are already offering Form 3 education to their students. Also contributing to the breakdown are moves towards a unified pay scale. While this debate may well be overdue educationally, it puts pressure on the teacher collective contracts, coverage of which depends on whether the school is classified primary or secondary. This in turn will produce competition between the teacher unions for members, unless proposals for amalgamation are renewed.

While this may seem fanciful, it can be argued that it was only a matter of time before the Minister's programme of "seamlessness" produced this pressure. The Government's support of a unified teaching service (and therefore unified staffing and pay scales) makes sense for its industrial agenda as well as for other educational and philosophical goals it may have (such as pay equity).

2. The new formula builds in a reduction of numbers of teachers in smaller schools, although the total pool of teachers is increased. That is, despite the provision of approximately 1000 extra teachers to the schooling system, smaller schools teaching levels Form 1 and above have lost teachers, and the larger schools have received disproportionately more of both the old and the new staffing resources. In sum, out of the total pool of teachers nation-wide, smaller schools with roll numbers less than approximately 575 students will get proportionately fewer teachers.

The MRG Report states, "The MRG proposals are aimed at smoothing resource entitlement for staffing more equitably ..." (p. 13). While this may be true numerically, it ignores the historical situation as laid out in Prime Minister Peter Fraser's famous 1939 statement on education:

The Government's objective, broadly expressed, is that every person, whatever his academic ability, whether he be rich or poor, whether he lives in town or country, has the right as a citizen to a free education of the kind for which he is best

fitted, and to the fullest extent of his powers.

Since that time, until the education reforms of 1989, there existed a commitment to fairness and equity for all students in New Zealand schools, no matter where this schooling took place. What the MRG report refers to is the historical situation whereby Form 1 and 2 education was resourced differently, depending on whether it took place in primary, intermediate, secondary or area schools. While at first glance inequitable, the extra assistance smaller rural schools used to receive was to ensure pupils in country areas received the same opportunities as pupils elsewhere, in the number of curriculum offerings provided. These have now been reduced, and this reduction, combined with the introduction of contestable funding for curriculum delivery, means that smaller rural schools will have to compete with each other for limited funding, and thus for survival.

It is interesting to note here that a paper on school staffing prepared for the Ministry of Education by a contracted consultant at the time the SCG was meeting, recommended that smaller schools should be given a $1.3 \%$ loading in resourcing if the staffing model later implemented through the MRG was proceeded with (Ellis, 1994). This was to compensate smaller schools for their relative disadvantage when the model was introduced, and to cushion them from the effect of the abrupt loss of teachers. This was not followed through into the MRG proposals, although the capped contestable pools are available to those schools.

3. Rural schools which meet specified criteria for isolation will have access to a pool of funding for innovative curriculum delivery, and can put forward applications for extra funding. This seems to be a compulsory trial of competition for smaller schools. The Report 
states, "The MRG believes that schools should explore the greater use of innovative ways of enhancing curriculum delivery. For example, distance education and the use of information technologies might lead to improved curriculum delivery without an increase in core staffing entitlement" (p. 17). In a recent circular to schools from the Ministry of Education (1995b) the use of itinerant subject specialists is also suggested. The total pool of funding available will not restore the total number of teachers lost to smaller schools. Efficiency gains will be made through the demand for innovation in order to give these smaller schools some ability to provide courses at a level comparable with larger schools. The funding will be delivered in cash, not teachers, thus progressing bulk funding even further.

4. Another contestable pool has been formed to support senior secondary/tertiary programmes which lead to National Certificate qualifications and which meet specified criteria related to higher costs. This appears to be a fund which, if schools succeed in winning money from it, would enable them to "purchase" courses for senior students from polytechnics or other tertiary institutions - thus furthering the contract model for services provided by the state (Boston, 1995) - or enable them to provide their own. It is interesting to note that this fund will not supply funding as of right to all schools with senior programmes. Thus, some schools will be able to supply wider opportunities to their senior students while others will not. On the one hand, the Government acknowledges a commitment to increase the skills of the young because, it is argued, this is necessary to keep New Zealand competitive. But on the other hand, it does not provide the increased funding for all schools to provide new courses. Presumably over time, schools will take their turn in receiving the additional funding, which raises the question of how courses set up through receipt of monies from the pool will continue in the lean years when government funding is not available. Funding from an alternative source, such as industry or parental fees, will have to be found until the next time the school's turn comes around.

It will be instructive to see which schools receive the additional funding and what purchasing programmes will receive governmental support. Presumably, those which succeed will then provide a ceiling towards which others will have to strive if they are to be competitive. They may well have to seek funding from elsewhere, private enterprise perhaps? Avondale College is an example of a school which has built a close relationship with industry of recent years, in their case, with Pepsi-Cola.
Since the MRG report, a third contestable pool has been announced by the Ministry, to be introduced at the same time. The third pool is for students at risk. The Ministry of Education Circular (1995b) states, "The pool is specifically for the establishment of projects. It is expected that, once established, the programme will be funded from within the school's own resources" (p. 7). Funding will be provided on an annual basis only.

5. In the process of the Staffing subgroup of the SCG, finalised in the Ministerial Reference Group, resources for those aspects of staffing which did not involve core curriculum delivery or management positions were pooled in the allocation through the formulae. This clearly has implications for those schools which had been allocated discretionary staffing.

6. The final part of the report addresses delivery mechanisms for school staffing. It is a Staffing First model that is presented. That is, the entitlement of schools to teachers is calculated first by formulae related to the number of pupils and teachers at the school. The school can then opt to receive the resourcing by central delivery, that is, employing the appropriate number of teachers, with their actual salaries paid centrally; or choosing direct resourcing by cash grant equivalent to the number of teachers to which they are entitled, multiplied by the average salary of a basic scale teacher. Under this option, the school can use the staffing resource for purposes other than employing teachers, if it so wishes.

The combined effects of implementation of the MRG proposals and developments since 1991 mean that compared with the end of 1991, almost the only section of the teaching staff which will not be bulk funded in 1996 relates to those on base salaries, that is, those without management responsibility. And even some base salary positions, those previously allocated on a discretionary basis, have been removed from staffing entitlement. A few secondary schools, however, have continued to make use of the provision whereby they can choose to have lower level management positions (PR1s and PR2s) funded centrally rather than through the SGM. More schools have opted to be bulk funded, but not in significant numbers. By March 1996, a total of 191 schools were fully bulk funded. Competition between schools, some more than others, has been introduced by reducing staff and creating contestable pools of funding. 
The struggle for the teacher unions in the latter part of 1995, then, was over the remaining part of base salaries not yet bulk funded. The years between 1991, the time of the last bulk funding fight, have seen a bulk funding "creep" with more and more of the teacher salaries budget being delivered to schools in cash rather than teachers. While the teacher unions are still maintaining a successful campaign in public over schools opting in to bulk funding, they have lost ground through regulatory announcements by the Ministry of Education, for example, over relief teachers, and now through the processes of the SCG and MRG.

\section{The Political Process of Achieving the MRG Report}

Government's achievements through the MRG of their stated goals of choice and competition between schools are considerable, and given the implacable opposition of the teacher unions to bulk funding, at first glance it appears surprising that so much progress has been made towards the agenda which provides the rationale for such opposition. It is tempting to postulate that while teachers and parents have been busy guarding the front door against the worst excesses of bulk funding, competition between schools has been sneaked in the back. The teacher unions have always based their opposition to bulk funding within the same theoretical perspective as that provided by Gordon in 1992. Has a whole strategic battle been overlooked?

What follows is a personal analysis over what happened - a response which is not necessarily shared by either union. I argue that the battle was not overlooked, but that both teacher unions have been working hard since 1991 to maintain both a professional focus on educational issues raised by the Government agenda and an industrial focus on improvements to pay and conditions on behalf of their members. These industrial demands have become increasingly insistent with the increase in workload from Tomorrow's Schools changes and curriculum and assessment reforms. Both unions, until the creation of the SCG, had been effectively excluded from educational decision-making structures since 1989. The SCG therefore represented an opportunity for the unions to be part of educational debates again. Participation by the unions in both the SCG and the MRG always carried with it the risk that the groups would be used by Government to advance their bulk funding policy.

Thus, it became a case of which battles, both against bulk funding and for improvement in pay and conditions, could be won by the unions in groups where Governmental bodies had the upper hand. The cumulative effect over time has meant that progress has been made towards a market system of education, a system which contains threats for the teacher unions in terms of their vision of a fair and equitable education system, and in terms of the breakdown of their national collective contracts. This was by no means a foregone conclusion, however, and has been accompanied by significant gains in both pay and staffing at the same time.

\section{The Schools Consultative Group ${ }^{1}$}

The Schools Consultative Group was formed in the wake of disputes over the two teacher collective contracts in 1992. This was the first time negotiations had taken place under the Employment Contracts Act 1991. As in other sectors where unions and employers were bargaining over contracts at that time, all sides felt insecure as to the limits and desirability of each others' and their own powers (Harbridge, 1993). The NZEI had settled its collective contract in July shortly after the introduction of the SGM legislation. The PPTA, which had not yet settled its contract, took the Government announcement of the introduction of SGM to be a provocative act in the middle of its negotiations. They responded with a moratorium on the curriculum initiatives of the Minister of Education, and each side proceeded to heighten hostilities until the August Annual Conference of the PPTA, which the Minister initially refused to attend. The NZEI also announced a curriculum moratorium later.

There are various accounts circulating as to the genesis of the SCG it might be fair to say that each party involved has a different story as to how it came into being. There does, however, appear to be some consensus that it was set up to provide a forum for debate on the mechanism for paying teachers' salaries, that is, a forum for negotiating over bulk funding. It was agreed among all parties that the polarisation of viewpoints might be resolved by the formation of a group containing representatives of the two teacher unions, the School Trustees Association and other interested parties, such as the Association of Bulk Funded Schools and the Association of Proprietors of Integrated Schools, under the Chairpersonship of John Anderson (later Sir John Anderson), Chairperson of the Wellington College Board of Trustees and Chief Executive Officer of the National Bank. Representatives of the Ministry of Education, ERO, the SSC and the Treasury were in attendance at meetings.

In the first four months of its existence, the group agreed to close entry to the TAG trial and to address other areas relating to the supply of resources to schools. This meant the study of both funding and staffing mechanisms. The unions lifted their moratoria on the Curriculum and 
Qualification Frameworks. An interim report to the Minister of Education in December 1993 commented on existing and possible delivery mechanisms for teacher salaries, and proposed delaying its recommendations until a Teacher Staffing Formulae Review subgroup had reported (Schools Consultative Group, 1993).

In the complex process of political negotiation that such groups entail, agreements reached had differing effects on each teacher union. In terms of bulk funding, the NZEI had more to lose than the PPTA over the implementation of the SGM. Because of the large number of small schools in the primary sector, with many sole charge principals, the SGM, applying only to management positions, effectively totally bulk funded those schools. For the PPTA, on the other hand, with clearly defined management positions and larger schools, the SGM produced very little change, as Boards were credited with the actual salaries of the teachers involved. The implementation of the SGM therefore was significant for primary schools in furthering bulk funding, much less so for secondary schools.

The setting up of the Teacher Staffing Formulae Review subgroup was a positive step forward for the NZEI in that it provided a forum for the pursuance of the Staffing Report on which it had been working through 1993, Review of Primary School Staffing. The report addressed the need to remove anomalies in the teacher/pupil ratio between small and large schools and to reduce over-large class sizes. To rectify these, an increase in the total pool of primary teachers was required. The secondary area, on the other hand, had seen a revision of its staffing system during the early 1980s. The allocation system devised then in the Secondary Staffing Report (Department of Education, 1983) targeted school staffing to the differing needs of the secondary school, and ensured an increase in staffing levels as both numbers of students and needs changed. The system functioned well for secondary schools, and was sufficiently flexible to suit the needs of self-managing schools. It was, however, a model which both delivered a fixed number of teachers, based upon the student roll, and also identified a fixed number of these positions for particular functions such as guidance counselling, and middle and senior management. This was a model not suited for virement between budget lines, as required by the public sector model. By participating in discussion of a unified staffing formula across both primary and secondary schools in the Staffing subgroup, the hard-won staffing gains of the PPTA in an earlier decade were up for re-negotiation in a forum where they could not be certain of the outcome.
In the deliberations of the Teacher Staffing Formulae Review subgroup some progress towards unified principles for the separate staffing systems was made (SCG, 1994). Papers were tabled by all parties, including some from the Ministry of Education, signalling that they were hoping to continue the implementation of bulk funding through the SCG. For example, the Ministry tabled a paper on implementing an EFTS 2 system in the senior secondary school (Ministry of Education, 1994). The work of the SCG came to a halt in September, 1994 when it made its final report to the Minister. By that time, positive progress was being made on primary staffing (from the point of view of the NZEI), the outlook was proving less positive for secondary staffing (in the view of the PPTA), and the Ministry appeared to be making progress both on a unified staffing system and towards its policy goal of bulk funding of teacher salaries. Over bulk funding, because there was no consensus, the final report of the SCG simply informed the Government that it had four options: retain the status quo; apply a type of bulk funding to all schools; offer Boards a choice of delivery mechanism; or apply partial bulk funding to all schools.

\section{The Ministerial Reference Group}

Soon after the demise of the SCG, the Minister of Education personally invited individuals, many of whom had been members of the SCG, to form a group to complete the unfinished work on the staffing formulae. This initiative of the Minister's is not surprising in light of the progress being made in the Staffing subgroup of the SCG towards bulk funding. The MRG was a preferable forum for the Government, in that its membership was formed by Ministerial invitation and was set up expressly with the purpose of advising the Minister on matters he wished to advance. It was stressed throughout the work of the group that members were present as individuals and were not to regard themselves as representative of any organisation. However, the people invited did form a representative group from NZEI Te Riu Roa, PPTA, the School Trustees Association, Te Kura Kaupapa Maori o Wairarapa, the Independent Schools Council, the Secondary Principals Association of New Zealand, the Intermediate School Principals Association, the Principals Federation, the Association of Proprietors of Integrated Schools, plus a principal and a representative of the Board of Trustees from the TAG schools. The group was serviced by the Ministry of Education. The SSC and the Treasury were not present in this forum. The contents of its report have been detailed above. 


\section{Conclusion}

It does appear that the neo-liberal agenda as described by Gordon in 1992 has been significantly progressed. Through the processes of the SCG and MRG the SGM was introduced; staffing formulae were changed to allocate teachers more closely to a per-pupil system; 122 more schools have opted to be fully bulk funded; and competition has been introduced through at least three targeted, capped contestable pools. On the other hand, it must be pointed out that in both situations where bulk funding per se has been progressed, in 1991 and at the present time, the opposition of the teacher unions has ensured that progress has been slow and that it has been accompanied by the allocation of extra resources by Government, thus effectively undermining the alliance between bulk funding and under-funding which has been typical of its introduction in other sectors.

The TAG trial was accompanied by extra funding to ensure schools did not suffer in the trials. And now, the achievements of the MRG have been accompanied by significant increases to the numbers of teachers overall. The rationale for teacher union opposition to bulk funding has always been that international experience shows that the introduction of bulk funding is accompanied by static funding of education, resulting over time in under-funding. Because of the gradual implementation of bulk funding in the schools sector in New Zealand, the under-funding is not occurring to the same extent, or so dramatically. But it would be fair to say that, at the moment, the Government has made substantial progress through the MRG report towards the goals of bulk funding, if not full bulk funding itself.

The teacher unions, although still enjoying the support of the majority of Boards of Trustees in not opting for full bulk funding, would appear to have lost some ground, in that more schools are still taking that option. We have argued that they have also lost ground in being unable to stop implementation of a series of capped, contestable pools, along with the efficiency gains which they are supposed to bring. However, other advances have been made, particularly with the addition of 1000 extra teachers to the system, overall. And it appears quite extraordinary that more than six years after the introduction of Tomorrow's Schools, one part of a comprehensive restructuring programme of all services provided by the state remains as a sector where the combined efforts of workers and governing bodies within the sector are still holding Government accountable for funding, rather than vice versa.

\section{Note}

1. The present paper does not allow space for a thorough discussion of all the politics and activities of the SCG and the MRG. It confines itself to the main developments over staffing which progressed the neo-liberal agenda. A forthcoming PhD thesis by Diane Pearce of Canterbury University looks at the existence of the SCG in depth.

2. The EFTS mnemonic stands for Equivalent Full Time Student, and is the unit for calculation of entitlement to bulk funding used in the tertiary sector.

\section{Glossary of Abbreviations}

ABFS

APIS

ASTE

ERO

ISC

ISPA

NZEI

MRG

PF

PPTA

SCG

SGM

SPANZ

SSC

STA

STAR

TSG

Association of Bulk Funded Schools

Association of Proprietors in Integrated Schools

Association of Staff in Tertiary Education

New Zealand Education Review Office

Independent Schools Council

Intermediate School Principals Association

New Zealand Educational Institute (renamed NZEI Te Riu Roa in July 1992)

Ministerial Reference Group on School Staffing

Principals Federation (for Primary Principals)

New Zealand Post Primary Teachers Association

Schools Consultative Group

Salaries Grant for Management

Secondary Principals Association of New Zealand

State Services Commission

School Trustees Association

Secondary-Tertiary Alignment Resource

Teacher Salaries Grant scheme

\section{References}

Boston, J. (Ed.). (1995). The state under contract. Wellington: Bridget Williams Books.

Dean, C. \& McGill, P. (1994, February 25). Schools caught in jobs-or-pay trap. Times Educational Supplement.

Department of Education. (1983). Report of the Secondary School Staffing Working Party. Wellington.

Edwards, W. (1993). Evaluation of Teacher Salaries Grant Scheme trial: First interim report: early experiences. Palmerston North: Massey University. 
Edwards, W. (1994). Evaluation of Teacher Salaries Grant Scheme trial: Second interim report: the second year. Palmerston North: Massey University.

Ellis, M. (1994). Review of teacher resourcing of schools. Wellington: Dialogue.

Gordon, L. (1992). The bulk funding of teachers' salaries: A case study in education policy. New Zealand Annual Review of Education, 1, 28-58.

Harbridge, R. (Ed.). (1993). Employment contracts: New Zealand experiences. Wellington: Victoria University Press.

Lauder, H. (1991). The Lauder report: Tomorrow's education, tomorrow's economy. Wellington: New Zealand Council of Trade Unions.

Maxwell, E. \& Rafferty, F. (1995, January 6). Governors seek cash as class sizes swell. The Times Educational Supplement.

Ministry of Education. (1994). Resourcing of teacher salaries: An investigation of an EFTS system. Discussion Paper. Wellington: Ministry of Education.

Ministry of Education. (1995a). Resource entitlement for school staffing: The report of the Ministerial Reference Group. Wellington

Ministry of Education. (1995b). Proposals pools - supplementary resources for 1996. Official Circular to Schools 1995/15. Wellington.

New Zealand Educational Institute. (1993). Review of primary school staffing: a discussion document. Wellington: NZEI.

Schools Consultative Group. (1993). The principles and mechanisms for the financing and payment of teachers' salaries: Report of the Schools Consultative Group. Wellington: Schools Consultative Group.

Schools Consultative Group. (1994). Staffing review: Report of the teacher staffing formulae review subgroup. Wellington: Schools Consultative Group.

Snook, I. (1995). The privatization of education. The 1996 Herbison Lecture, presented at the Annual Conference of the New Zealand Association for Research in Education, Massey University, Palmerston North.

Wylie, C. (1995). Contrary currents: The application of the public sector reform framework in education. New Zealand Journal of Educational Studies, 30 (2), 149-164.

\section{Acknowledgements}

I would like to thank both the NZEI Te Riu Roa and the PPTA for access to their files and generous assistance with this paper.

\section{The author}

Gay Simpkin is a Lecturer in Labour and Trade Union Studies at The University of Waikato. Until recently, she was employed by PPTA as an advisory officer working in the area of bulk funding and staffing. She is currently writing a doctoral thesis on the 1989 industrial negotiations of the personnel provisions of Tomorrow's Schools. 